\title{
South East Asia's Megalodon shark first record and habitat preference modeling during Miocene period (20 Ma) and winter monsoon impacts in South coast of West Java
} Andri Wibowo*

Keywords: habitat use, model, megalodon, Java, shark

*U. o. Indonesia, West Java, 16424. Indonesia. Correspondence email: paleobio2020@gmail.com

\begin{abstract}
Otodus megalodon is known as the biggest shark ever alive and recent records show this species was only existed in America, Africa and Europe continents in the last Miocene period 20 million years ago (Ma). Recently, megalodon teeth have been discovered in South coast of West Java. Here this study aims to present and model the presence of O. megalodon. The length of the excavated tooth was ranging from 13 to $19 \mathrm{~cm}$. The lithological analysis shows that the tooth was found in Miocene rock layers. Paleogeographic model shows that during Miocene southern parts of Java island were submerged including the recent locations where the megalodon tooth have been found. Half parts of the modeled West Java were an ocean with depth ranging from 0 to $200 \mathrm{~m}$. High habitat use preferences by juvenile megalodon were estimated in the shelf (depth 0-40 m) with the size of $1365 \mathrm{~km}^{2}$. Whereas habitat use preference by adult megalodon was low at this depth. Both juvenile and adult habitat use frequencies were low at a depth of between $80 \mathrm{~m}$ and $160 \mathrm{~m}$. Habitat use preferences were increasing at a depth of $>200 \mathrm{~m}$. After Miocene, the paleoclimate records show a decline in temperature and lead to the decline of whale population in ocean. The declining of megalodon's prey explains the declining of this giant shark especially in post Miocene and early Pliocene periods.
\end{abstract}

\section{Introduction}

Prehistoric periods were characterized by gigantic animals as can be seen in lands. In sea, there are also the giants including megalodon sharks. An extinct giant shark scientifically name Otodus megalodon (previously Charcarocles megalodon) is the last member of the predatory megatoothed lineage and is reported from Miocene (20 million years ago) to Pliocene periods from nearly all continents (Boessenecker et al. 2019). Based on fossil records, the global O. megalodon distributions including South America (Bahia Inglesa, Mina Fosforita, Punta la Gorda, Punta la Colorada,), Britain (Beaumaris), Australia (Batesford), North America (Tamiami, Gatun), Europe, Africa, and New Zealand (Wellington) (Keyes 1972, Pimiento et al. 2016). Those fossils were found either in coasts or in lands and this indicates that during prehistoric periods a terrestrial land today was a bottom of the sea in the past. A process called 
continental drift has caused a bottom of the sea become dry land as can be seen today. Despite its globally distribution, reports of $O$. megalodon in Asia continents are still limited with the only report was from coast of Brunei (Kocsis \& Razak 2018).

Java island is known as one of island in South East Asia with high diversity of animals from prehistoric periods. In land several animal fossils represent prehistoric animal have been found. Whereas records on aquatic prehistoric animal are still scarce. This is contradicted to the geographical facts that Java island is surrounded by sea and ocean. In current time, sea around Java island has vast biodiversity including extant sharks accounted for 118 species under 25 families (Yudha et al. 2018). Here, this study aims to explore the presence of megalodon and model the habitat use preference of this species mainly in Java island.

\section{Methods}

\section{Study area}

The study area was the South coast of West Java of Java island (Figure 1). Coastal area was selected based on the lithographic characteristic that represent Miocene period. South coast of Java island was bordered directly with India ocean and ocean with its vast areas where more suitable habitats for large sharks. The excavated tooth was compared with results from Cooper et al. (2020) for identification purposes based on tooth shape and morphological characters.

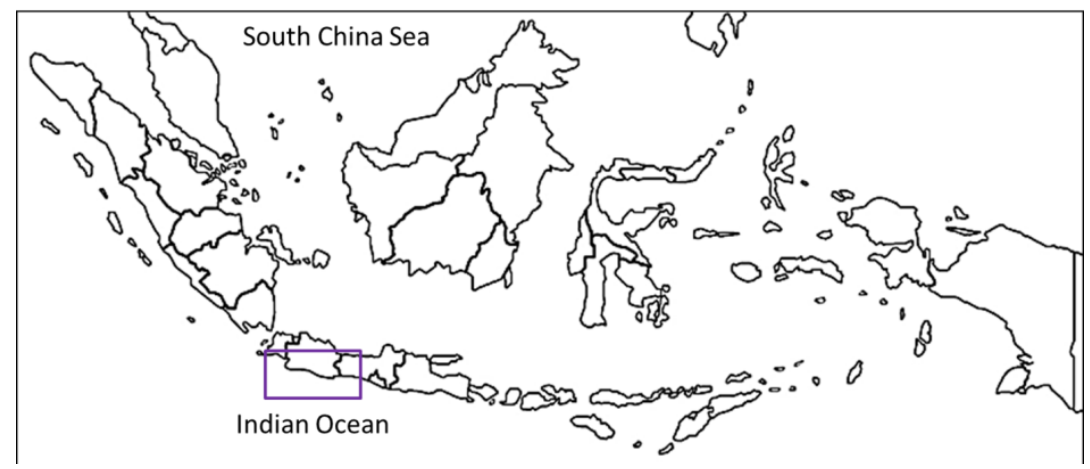

Figure 1. Study area (purple rectangle) bordered directly with Indian Ocean in the south

\section{Miocene ocean and habitat modeling}

Miocene ocean was reconstructed referred to the location were the megalodon fossil was found. The modeled Miocene ocean then used to estimate the habitat uses of extint megalodon. Estimates of megalodon habitat uses follow method by (Cooper et al. 2020) by using the extant great white shark (Carcharodon carcharias) habitat uses as the only modern analogue. Habitat modeling was made for juvenile and adult megalodon using the water depth as the function of habitat use preference. 


\section{Results}

In South coast of West Java, there were 2 particular locations were megalodon tooth fossil can be founds. Those locations were Surade in west and Cimindi villages in east that were separated $200 \mathrm{~km}$ each other. Surade was located $5 \mathrm{~km}$ from the Indian ocean and $15 \mathrm{~km}$ for Cimindi. The megalodon tooth excavated was sizing 13-19 cm for its length and 14 for its base (Figure 2). In Surade, the teeth were deposited in rock and soil layers. Based on lithological records, the soil and rock layers were from Miocene period (Figure 3)
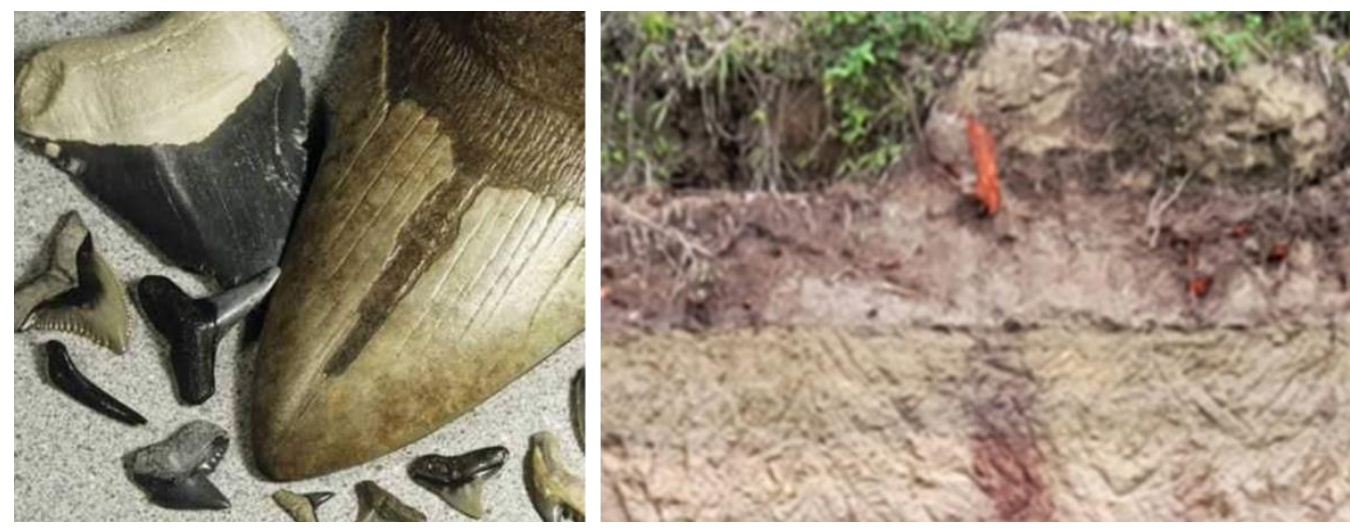

Figure 2. The excavated megalodon teeth fossils (left) and soil rock layers (right) containing fossils in Surade in South coast of West Java.

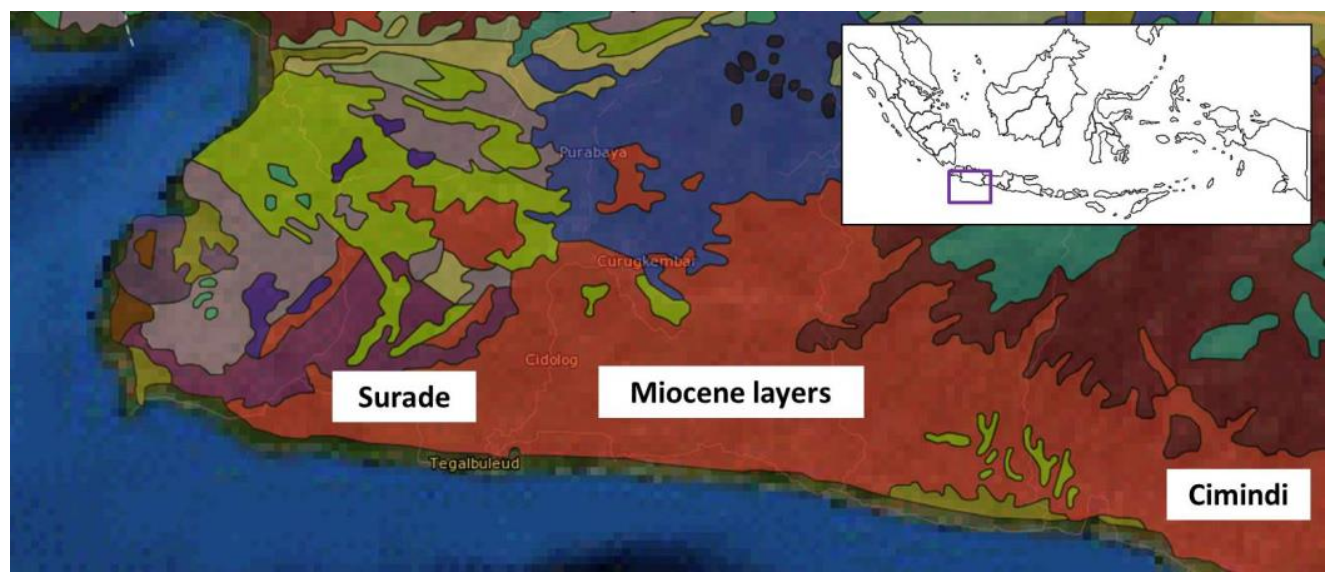

Figure 3. The localities of megalodon tooth fossils in Surade and Cimindi in South coast of West Java. 
Based on ocean modeling the Surade and Cimindi villages were submerged by the ocean during Miocene period. In fact in $20 \mathrm{Ma}$, almost half of the Java island was an ocean with the Miocene period coast line was located $50 \mathrm{~km}$ from the current coast line (Figure 4). The South coast of Java then modeled with ocean submersion at depth of $40 \mathrm{~m}$. In this model, one of megalodon fossil localities in Surade is already submerged by Indian ocean (Figure 5). The submersion model then was developed up to $200 \mathrm{~m}$ depth referring to the depth of megalodon habitat. At this depth, half of South coasts of West Java was submerged and become the parts of Indian Ocean referring to the past Miocene period (Figure 6). The submersion model was presented in the bathymetry model and the Miocene coast was located $50 \mathrm{~km}$ from the current coast line.
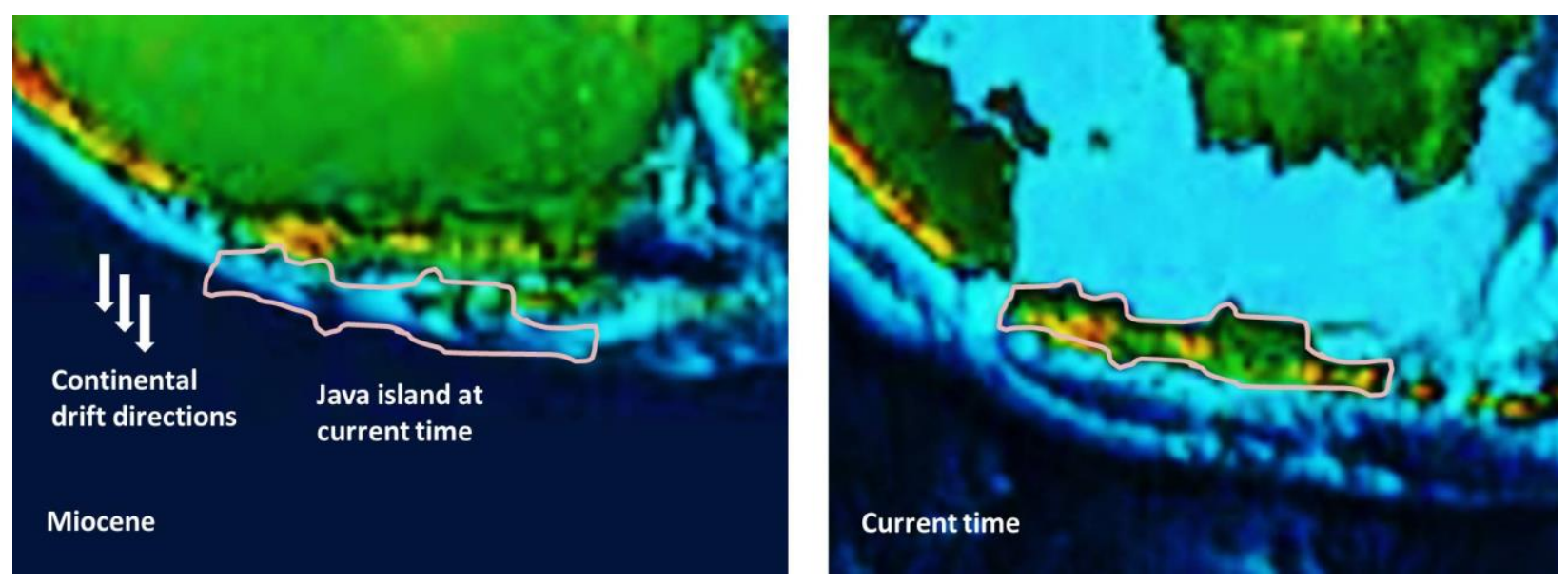

Figure 4. Java island during Miocene period 20 million years ago.

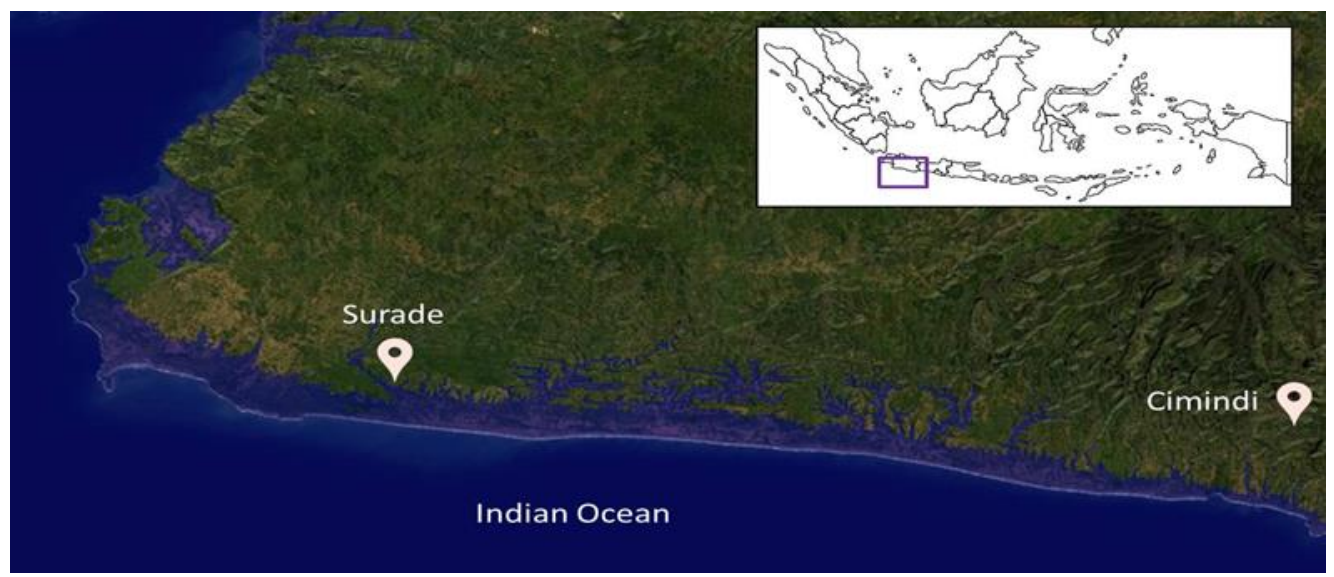

Figure 5. Model of submerged South coast of West Java at $40 \mathrm{~m}$ depth scenario 


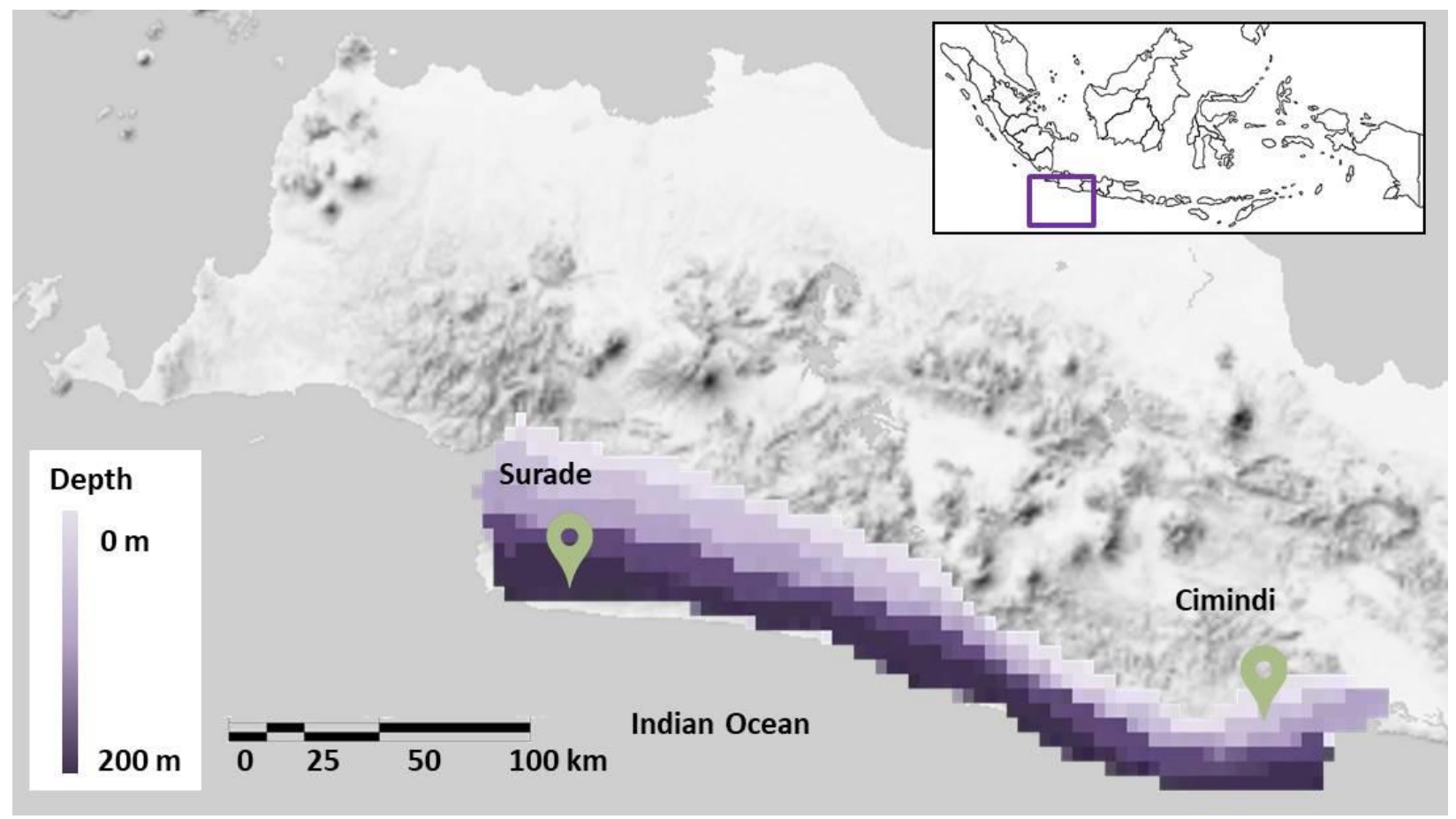

Figure 6. Bathymetry model of submerged South coast of West Java during Miocene period.

Figure 7. shows modeled habitat uses of megalodon estimated for juvenile and adult using extant Carcharodon carcharias as references. Juvenile was more common in coast at depth of $0-40 \mathrm{~m}$ in comparison to adult. Whereas habitat use preference by adult megalodon was low at this depth but increasing at depth of 40-80 m. Juvenile and adult habitat use frequencies were low at a depth of between $80 \mathrm{~m}$ and $160 \mathrm{~m}$. Habitat use preferences were increasing at a depth of $>200 \mathrm{~m}$ (Figure 8). 

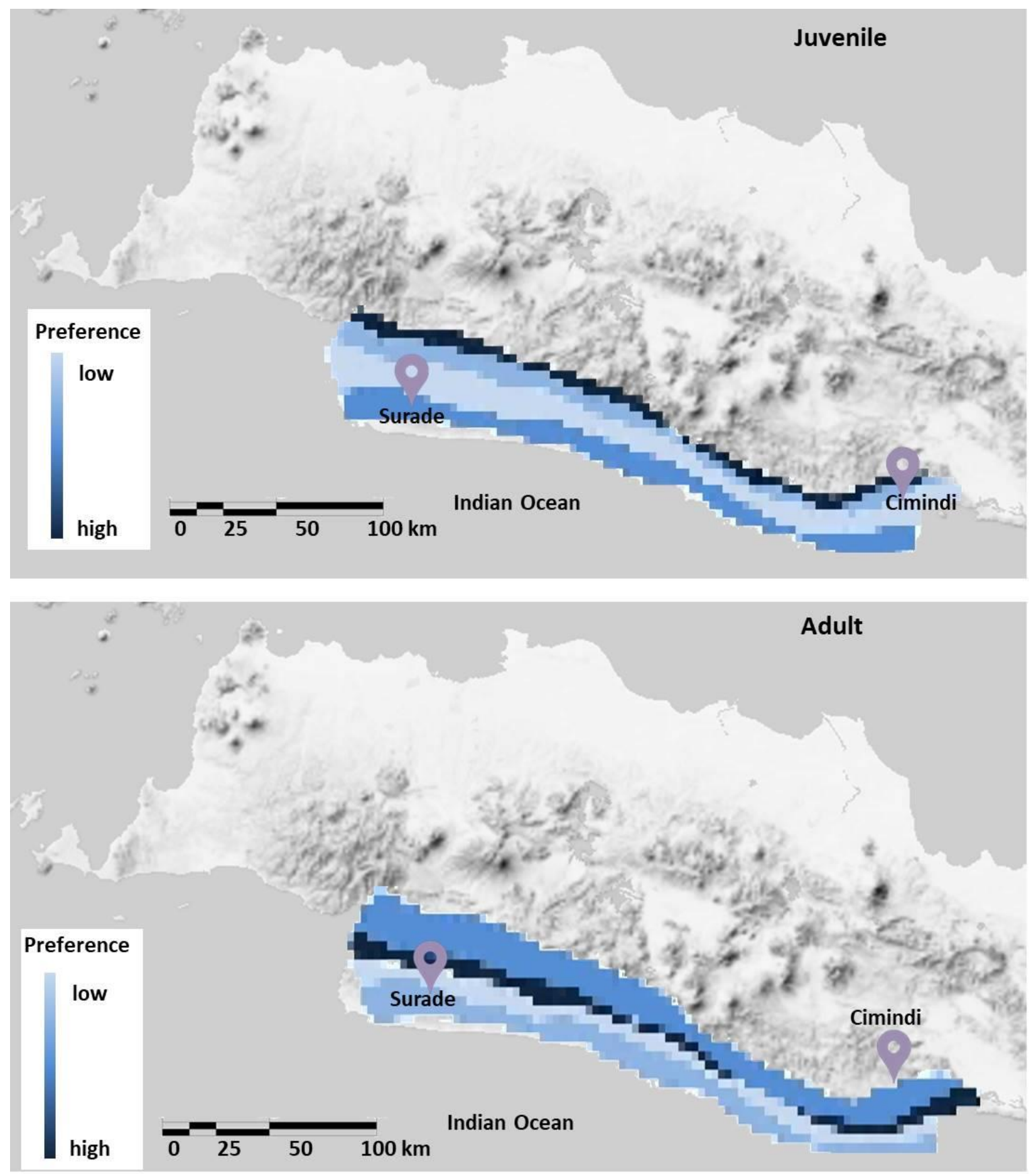

Figure 7. Habitat preference model of juvenile and adult megalodon in South coast of West Java during Miocene period. 


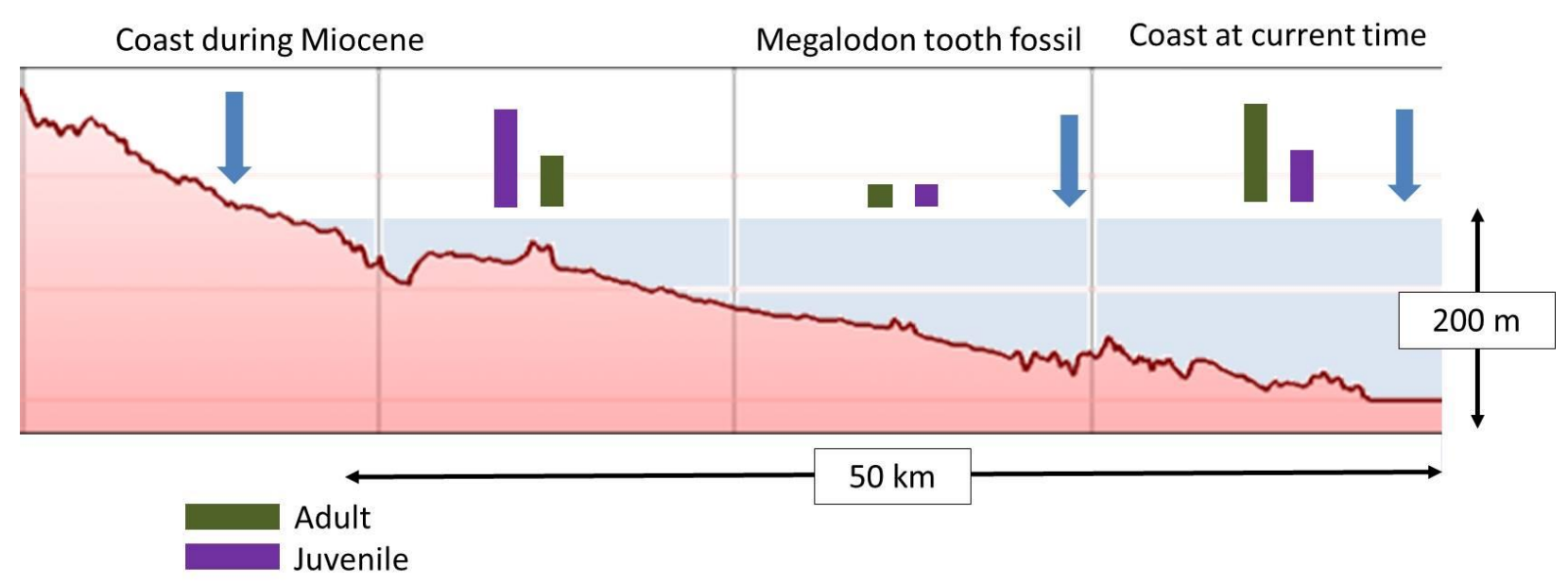

Figure 8. Habitat preference model of juvenile and adult megalodon in South coast of West Java during Miocene period (cross sectional view).

\section{Discussion}

Presences of megalodon in South coast of West Java represented by teeth fossils were comparable to other studies. Java island was inhabited by numerous prehistoric shark species. Yudha et al. (2018) have reported findings of tooth representing 11 shark genus from 7 shark families sampled from coasts and inlands. Those genus included Carcharhinus. Negaprion, Galeocerdo, Scoliodon, Sphyrna, Hemipristis. Alopias. Carcharias, Parotodus, Isurus.and Carcharodon. The soil and rock layers where the megalodon fossil was found was also comparable to the periods when megalodon exist as reported by other literatures that is from the Miocene to the Pliocene (23-2.6 Ma). Periods of soil layers in Surade and Cimindi were estimated from Miocene period.

Habitat preferences of megalodon were modeled using extant great white sharks as an analog. In the model in this study, a shallow shelf water was considered as preferred habitat. Sharks mostly remained within shelf waters in depths $<100 \mathrm{~m}$ with occasional dives to depths $>1000 \mathrm{~m}$. During Miocene period, megalodon was estimated has traveled to deepest parts of Indian ocean located in South of West Java coast. As a comparison, extant great white shark has travelled over a long distance exceeding an estimated $1000 \mathrm{~km}$ in length (Bradford et al. 2020). Megalodon juvenile was modeled having higher habitat preferences at shallow water near the coast and at depth of $>200 \mathrm{~m}$. Based on observation of extant shark, Weng et al. (2007) have reported juvenile sharks have occasionally displayed deeper movements and vertical excursions reaching depth of $226 \mathrm{~m}$. Shallow water excursions at depth of $26 \mathrm{~m}$ were observed mainly during dawn, day and dusk. Whereas, increase in the use of deeper waters by sharks is more frequent in adult (Curtis et al. 2014). Kocsis and Razak (2018) stated that megalodon juvenile prefers shallow marine coastal settings either looking for accessible food resource including 
smaller sharks, rays and bony fishes and avoiding larger predators including adult megalodon or toothed whales.

Declining of megalodon population has been reported globally. Onset of megalodon population decline probably started in the late Miocene with a decrease in its global abundance and followed by a decline in its geographical range during the Pliocene. Population decline of megalodon has been attributed to intertwined of climate change and drop in the diversity of filter-feeding whales as the primary factors (Pimiento et al. 2016) and the appearance of new competitors (large predatory whales and the great white shark) as secondary factors. Considering its size, megalodon required ample prey as its diets. Megalodon inhabiting southern hemisphere including Indian Ocean was estimated larger than megalodon living in northern hemisphere (Pimiento and Balk 2015). Megalodon population decline was an impact of declining prey caused by climate change. At the beginning of Miocene, diversity and abundance of marine mammals including small whales were high. Whereas, later during the Pliocene, there was a climate change in the form of drop in ocean temperatures that likely contributed to the declining of megalodon preys followed by megalodon populations. Post middle Miocene oceanographic climate changes and cooling sea surface temperature may have resulted in megalodon range fragmentation and alongside competition with the newly evolved great white shark (Carcharodon carcharias) has also contributed to the megalodon population declines.

Post middle Miocene oceanographic and sea surface temperature cooling as determinant factors are more significant mainly in South East Asia water in the form of winter monsoon (Holbourn et al. 2018). Based on high-resolution benthic isotope record combined with paired mixed layer isotope and $\mathrm{Mg} / \mathrm{Ca}$-derived temperature data, a long term cooling trend synchronized with intensification of the Asian winter monsoon from $7 \mathrm{Ma}$ until 5.5 Ma have been detected. Changes in the carbon cycle involving the terrestrial and deep ocean carbon reservoirs were determinant factors of Miocene climate cooling.

\section{Conclusions}

This study is the first that has reported the presence of megalodon in South East Asia. Along with the first record, a habitat use preference of megalodon has been developed. During Miocene period, 20 million years ago, southern parts of West Java island were submerged and becoming the parts of Indian Ocean and providing suitable habitats for megalodon population.

\section{References}

Boessenecker R, Ehret D, Long D, Churchill M, Boessenecker S, Martin E. 2019. The Early Pliocene extinction of the mega-toothed shark Otodus megalodon: a view from the eastern North Pacific. PeerJ. 7.

Bradford R, Patterson TA, Rogers PJ. 2020. Evidence of diverse movement strategies and habitat use by white sharks, Carcharodon carcharias, off southern Australia. Mar Biol 167: 96. 
Cooper JA, Pimiento C, Ferrón HG. et al. 2020. Body dimensions of the extinct giant shark Otodus megalodon: a 2D reconstruction. Sci Rep 10.

Curtis TH, McCandless CT, Carlson JK, Skomal GB, Kohler NE, Natanson L. 2014. Seasonal Distribution and Historic Trends in Abundance of White Sharks, Carcharodon carcharias, in the Western North Atlantic Ocean. PLoS ONE 9(6).

Holbourn AE, Kuhnt W, Clemens SC. 2018. Late Miocene climate cooling and intensification of southeast Asian winter monsoon. Nat Commun 9., 1584.

Keyes IW. 1972. New records of the Elasmobranch C.megalodon (Agassiz) and a review of the genus Carcharodon in the New Zealand fossil record, New Zealand Journal of Geology and Geophysics. 15(2): 228-242.

Kocsis L, Razak H. 2018. Late Miocene Otodus (Megaselachus) megalodon from Brunei Darussalam: Body length estimation and habitat reconstruction. Neues Jahrbuch für Geologie und Paläontologie - Abhandlungen. 288. 299-306.

Pimiento C, Balk MA 2015. Body-size trends of the extinct giant shark Carcharocles megalodon: a deeptime perspective on marine apex predators. Paleobiology.;41(3):479-490.

Pimiento C, MacFadden B, Clements C, Varela S, Jaramillo C, Velez-Juarbe, J, Silliman B. 2016. Geographical distribution patterns of Carcharocles megalodon over time reveal clues about extinction mechanisms. Journal of Biogeography.

Yudha DS, Ramadhani R, Suriyanto RA, Novian MI. 2018. Prehistoric sharks in Indonesia.

Weng K, Lowe C, Winkler C, Block B. 2007. Movements, behavior and habitat preferences of juvenile white sharks Carcharodon carcharias in the eastern Pacific. Marine Ecology-progress Series 338: 211-224. 